\title{
Modern approaches to the management of material and technical support in integrated agricultural facilities
}

\author{
Shamil M. Gazetdinov*, Mirsharip Kh. Gazetdinov, Olga S. Semicheva, and Farida F. Gatina \\ Kazan State Agrarian University, Kazan, 420015, Russia
}

\begin{abstract}
The article discusses the ways to increase the efficiency of the use of commodity stocks and supplies in the course of production and sale. It is argued that the improvement of the organization of material management is one of the most important factors in the increase of the efficiency of using huge volumes of raw materials in agricultural production along with the introduction of new equipment and technology. The implementation of this concept in large agricultural facilities provides savings of millions of rubles a year by reducing the level of stocks, accelerating the turnover of funds invested in materials, technical equipment, etc., which gives the same profit growth as the increase of the sales of products by $20 \%$. The main tools of the mechanism for the mobilization of these reserves are considered: further improvement of the existing linear-functional apparatus due to the redistribution of rights and responsibilities for the management of the material and technical flow between different units in order to coordinate their work and the use in the field of stock management of logistics structures. It is proposed that in the formation of logistics systems, the main attention should be focused not so much on organizing the work of each of the functional subsystems of management individually, but on the coordination of their efforts to achieve the ultimate goals of integrated agricultural formation.
\end{abstract}

\section{Introduction}

At the present stage of economic development in the practice of integrated agricultural formations, due attention is paid to the improvement of the efficiency of the use of raw materials, materials and equipment coming into production consumption, as well as the reduction of costs associated with the movement of the entire set of material and technical supply in the course of production and sale. First of all this is due to a significant increase in this group of expenses, which, according to some estimates, constitutes on average $60 \%$ of the total production costs for many agricultural enterprises [1].

The reduction of these costs is considered by many economists as one of the main ways to increase the profitability of the functioning of large integrated units in the context of accelerating the pace of scientific and technological progress and intensifying crisis phenomena in economy. In recent years, it has become clear that improving the organization of material resources management, as well as new technologies and technologies, is one of the main factors for increasing the efficiency of using a large number of raw materials and agricultural products.

Moreover, it is necessary to note that the larger the integrated formation, the more difficult management of the numerous flows of raw materials, materials and finished products passing through production and marketing divisions. Therefore, the formation of the most rational stock management system in these conditions will become more important.

\section{Materials and Methods}

For example, research shows that reducing the cost of materials and supplies associated with pre-production in large agricultural units provides a $20 \%$ increase in revenue, such as increasing sales by just one percent, reducing inventory, materials, technology, and so on. [2].

In addition, research has confirmed that the effectiveness of the work closely depends on measures for the implementation of the investment project. Thus, only in the agro-industrial complex "Krasny Vostok agro" 14 billion rubles were invested in the development of animal husbandry in the dairy industry, and in Europe the largest 13 megaferm tikilib was put into operation. Over the 14 years of its operation, the number of cattle has increased from 16,200 to 65,000 , that is, 4 times. At the same time, the production of meat has increased three times, and milk-about five times (from 23,100 tons per year to 116960 tons per year).

First of all in this case it is important to rationally use production facilities and technical means. In recent years the process of enlargement of dairy farms in other agricultural formations has appeared. In particular, some agricultural enterprises brought the number of cows to 2,000 or more in one area. At the same time, according to the studies of agricultural enterprises of the Republic of Tatarstan, more than half of the total number of cows

Corresponding author: gazetdinov.shamil@yandex.ru 
in the republic is kept on small farms - up to 100 heads, and they produce most of the milk yield. In most of these farms manual labor has been preserved in certain production and technological processes, the costs of which for obtaining 1 hundredweight of milk reach are 5-6 man/hours (Table 1).

Table 1. Technical and economic indicators of various farms in $2018 *$

\begin{tabular}{|l|c|c|c|}
\hline \multicolumn{1}{|c|}{ Indicators } & $\begin{array}{c}\text { Farm for } \\
1200 \text { cows }\end{array}$ & $\begin{array}{c}\text { Farm for } \\
400 \text { cows }\end{array}$ & $\begin{array}{c}\text { Farm for } \\
100 \text { cows }\end{array}$ \\
\hline $\begin{array}{l}\text { Construction } \\
\text { budget, thousand } \\
\text { rubles }\end{array}$ & 134528.0 & 41231.0 & 12703.0 \\
\hline $\begin{array}{l}\text { Capital investments } \\
\text { per 1 cattle place, } \\
\text { thousand rubles }\end{array}$ & 112.1 & 103.07 & 127.03 \\
\hline $\begin{array}{l}\text { Cost of equipment } \\
\text { for 1 cattle place, } \\
\text { thousand rubles }\end{array}$ & 56.79 & 24.2 & 27.13 \\
\hline $\begin{array}{l}\text { Milk yield from one } \\
\text { cow, h }\end{array}$ & 55.95 & 55.95 & 55.95 \\
\hline $\begin{array}{l}\text { Cost of 1 } \\
\text { hundredweight of } \\
\text { milk, rub. }\end{array}$ & 1793.4 & 1673.2 & 1736.4 \\
\hline $\begin{array}{l}\text { Labor costs per 1 } \\
\text { hundredweight of } \\
\text { milk, man/hour }\end{array}$ & 1.27 & 2.43 & 5.81 \\
\hline $\begin{array}{l}\text { Standard profit, } \\
\text { thousand rubles }\end{array}$ & 9171.67 & 2801.07 & 811.0 \\
\hline
\end{tabular}

* the calculations of authors according to the Ministry of

Agriculture and Food of the Republic of Tatarstan

Meanwhile, the experience and practice of large integrated agrarian facilities show that the equipment produced today can be mechanized and automated in a comprehensive manner. Digital technologies can be introduced to all production and technological processes and on small farms [3].

As it can be seen from the table, the technical and economic indicators of these farms are distinguished in comparison with medium-sized farms for 400 cows. Small farms for 100 and 200 cows can be cost-effective. They are most suitable for peasant (farm) households. The creation of mega-farms (for 1.5-2 thousand cows and more), especially in farms with a limited forage base and non-grazing animals, often leads to the decrease in their productivity and deterioration in reproductive functions (cow yeldness reaches 20-25\%), which causes increased culling.

The increasing influence of costs associated with materials on the final results of operations (i.e., profit) has forced many integrated groups to significantly restructure the organizational forms used earlier and in some cases completely reconsider the approach to the management of material and material and technical supply, the place of the corresponding services in the organizational structure, the status and responsibilities of the leader responsible for the efficient use of stock in the organization, etc. [4].

In particular, the reduction of prices of construction of dairy complexes is one of the most important areas of the struggle to increase their effectiveness. Now the cost of one cattle place in the livestock farms built in recent years is 103-127 thousand rubles and more. In the total cost of building farms, the share of the cost of equipment for keeping animals is 50.66, 23.48 and $21.36 \%$ depending on the size of the farms (1200, 400 and 100 respectively), the remaining costs are for the main production facilities, utility and auxiliary buildings (veterinary, administrative, utility). In general, in order to increase the efficiency of capital investments, it is important to choose not only the most economical version of equipment, but also to ensure its most complete and intensive use. In addition, it is necessary to take into account other costs, the costs of transporting feed and manure, labor supply, etc.

Nowadays, the Republic of Tatarstan ranks first place in terms of milk production in the Volga Federal District. The specific weight of Tatarstan in the all-Russian milk production is $5.85 \%$, in the Volga Federal District $19.17 \%$, respectively, with the specific weight of the number of cows being 4.30 and $16.92 \%$ (Table 2).

Table 2. The share of dairy cattle in the Russian Federation in $2017^{*}$

\begin{tabular}{|l|c|c|c|c|c|}
\hline \multicolumn{1}{|c|}{ Indicators } & RF & PFD & RT & $\begin{array}{c}\text { RT to } \\
\text { RF, } \\
\%\end{array}$ & $\begin{array}{c}\text { RT to } \\
\text { PFD, } \\
\%\end{array}$ \\
\hline $\begin{array}{l}\text { The number of } \\
\text { cows, thousand }\end{array}$ & 8225.9 & 2093.6 & 354.2 & 4.30 & 16.92 \\
\hline $\begin{array}{l}\text { Milk } \\
\text { production, } \\
\text { thousand tons }\end{array}$ & 31183.5 & 9515.3 & 1823.8 & 5.85 & 19.17 \\
\hline $\begin{array}{l}\text { Per capita } \\
\text { consumption of } \\
\text { milk and dairy } \\
\text { products per } \\
\text { year, kg }\end{array}$ & 231 & 266 & 362 & 156.7 & 136.1 \\
\hline
\end{tabular}

* the calculations of authors according to the Federal State Statistics Service

The consumption of milk and dairy products in the republic is higher in comparison with other subjects of the federation and is close to the norm of consumption, $380 \mathrm{~kg}$ per capita.

The republic has the necessary conditions for the effective functioning of the dairy industry. The industry's profitability in 2017 was $25.4 \%$, in $2018-9.8 \%$. The dynamics of profitability was reflected in the decrease of 285 rubles in the selling price of milk in 2018. In general, in 2018, a profit of dairy cattle breeding amounted to 1812.3 million rubles. At the same time, the studies show that due to objective and subjective factors, the number of cows decreased by 3.3 thousand heads. Despite this, milk production per 100 hectares of agricultural land has a steady growth trend and increased in 2018 by $15.9 \%$ compared to 2014 . All this is ensured by the improvement of the feed supply and the breed composition of the milking herd (Table 3 ).

Thus, further development of the agricultural sector of the economy of the Republic of Tatarstan, in particular, dairy cattle breeding, and the increase of its efficiency should be carried out through the creation of a competitive environment in the production and sale of products [5]. Investments in the dairy cattle industry 
should pay off in 7-8 years (calculating their economic efficiency by a standard method). However, this period can be significantly reduced due to the correct choice of projects for premises, a complex of machines and equipment, as well as their high-performance use and the increase of the level of breeding.

Table 3. Development trends of dairy cattle breeding in agricultural organizations of the Republic of Tatarstan *

\begin{tabular}{|l|c|c|c|c|c|c|}
\hline \multicolumn{1}{|c|}{ Indicators } & 2014 & 2015 & 2016 & 2017 & 2018 & $\begin{array}{c}2018 \text { to } \\
2013, \%\end{array}$ \\
\hline $\begin{array}{l}\text { The number of } \\
\text { cows, thousand }\end{array}$ & 247.8 & 249.7 & 249.8 & 243.9 & 244.5 & 98.67 \\
\hline $\begin{array}{l}\text { Average milk } \\
\text { yield from 1 feed } \\
\text { cow, h }\end{array}$ & 48.09 & 49.90 & 51.20 & 55.50 & 55.95 & 116.3 \\
\hline $\begin{array}{l}\text { Milk production } \\
\text { per 100 ha of } \\
\text { farmland, } h\end{array}$ & 283 & 295 & 303 & 322 & 328 & 115.9 \\
\hline $\begin{array}{l}\text { Harvested coarse } \\
\text { and succulent } \\
\text { fodder per 1 head } \\
\text { of cattle, h of } \\
\text { feed units }\end{array}$ & 29.9 & 33.3 & 30.9 & 40.4 & 31.9 & 106.7 \\
\hline
\end{tabular}

* the calculations of authors according to the Federal State Statistics Service

\section{Results and Discussion}

The search for new organizational forms to improve the efficiency of investment is performed in two main directions. The first direction is connected with the further improvement of the existing linear-functional apparatus due to the redistribution of rights and responsibilities for the management of the material and technical flow between different units in order to coordinate their work, the second direction is connected with the attempts to use the structures of the logistics system in this area.

The main purpose of the restructuring traditional linear-functional structures is to overcome their internal contradictions and shortcomings, the presence of which does not allow the effective solution of complex problems in the field of logistics management that many large agricultural formations have faced in the last two decades.

For example, often the main production management subsystem controls the work of the supply department for the supply of raw materials, delivery dates, level and stock list, etc. [6]. The marketing subsystem is responsible for storing finished products and bringing them to consumers. The financial management subsystem controls the efficiency of the use of materials and costs associated with the movement of the flow of materials and finished products through integrated formation [7].

Practical experience shows that the mechanism works quite effectively in the provision of complex services and in the process of using the services of regular suppliers and in conditions of minimal production in the process of distributing products to certain groups of consumers [8].
But when integration occurs under the influence of a competitive environment, the company must update the product range, create a system of industrial relations, but with a clear division of tasks in the field of logistics management, traditional structures can ensure effective use. As a result, increased production space and retail inventory, reduced working capital for raw materials and finished products, increased transportation and storage costs, improved customer service, and so on.as a result, this leads to large financial losses.

The dispersed state of responsibility for the management of logistics and material and technical supply between mid-level units leads to the fact that the organization does not have an official, except for the directly senior manager, who are responsible for the improvement of the efficiency of use of the entire volume of material and technical supply and able to provide prompt resolution of numerous conflicts that arise in this area during supply chain activities. Thus, for example, the subsystem for the management of the main production seeks to have a large insurance stock of raw materials and to produce a limited, rarely changing product range.

The marketing subsystem of active market policy is, on the contrary, interested in constantly expansion of the assortment, having the maximum possible volume of storage and processing of finished products in order to increase the competitiveness of products and ensure the expansion of sales. On the contrary, the financial management subsystem seeks to reduce all types of stocks and costs that adversely affect the financial performance of integrated facility.

This inconsistency of goals in the field of logistics management, in which each functional subsystem must constantly overcome the resistance of other subsystems, leads to numerous conflict situations regarding the coordination of the level and structure of stocks, delivery methods, supply schedules, etc., especially during continuous expansion of production.

First of all the disadvantages of the described traditional scheme are in the fact that all the threads of material resources management are concentrated on the senior manager. This fact prevents the quick solution of cross-functional problems, a large number of which arise in large integrated facilities. In this context, there is an urgent need to develop additional integrated and coordinated mechanisms to ensure continuous inventory management throughout the organization based on the centralized design and management functions of logistics management.

A study of the experience of the integrated facilities of the Republic of Tatarstan such as "Agrosila Group" and "Krasny Vostok Agro" on the use of specialized units for the management of logistics indicates that the concentration of power and responsibility for the efficient management of stock flow allowed not only significant increase of the level of the use of raw materials, but also reduction of the costs associated with their movement and storage.

The structure of "Agrosila Group" includes 25 agricultural enterprises in 10 areas of activity located in an area of 330 thousand hectares. "Krasny Vostok Agro" 
consists of 5 breeding enterprises located in 4 regions of the republic uniting 59 livestock farms, 7 grain receiving centers, 3 feed production facilities with a total storage capacity of 300,000 tons and 1 seed plant with a capacity of 120,000 tons of seeds per year. It occupies 265,000 ha of land and has more than 20,000 units of modern agricultural machinery.

The activities of these integrated facilities are characterized by a significant scale of production, the novelty and complexity of the technology, extensive production and marketing relations. Exactly in such difficult conditions there is a need for organizational forms that would ensure not only control from a single center over the use of all types of resources and reserves on an integrated facility scale, but also the possibility of flexible restructuring and coordination of the actions of all functional units involved in the management of stock values. Exactly in this direction the main efforts of many specialists in digital technologies are currently focused. They see the creation of such logistics structures as one of the main ways to solve the complex set of problems that many large integrated agricultural organizations face now and increase the efficiency of the use of growing volumes of material and technical supply.

The theoretical foundations of a new way to restructure the existing organizational form in the field of logistics and inventory management, a model of logistics management system are considered. This method has two main features. First, it is necessary to create a single integrated management system that includes the design and control of the entire range of raw materials used from the supplier's production facilities, the final product is delivered to the consumer through the sales subsystem. The second aspect is the fact that the management process should be based on a general indicator of the effectiveness of the use of stock in integrated facilities, which is formed not only at the stage of sale, but also during the implementation of three main material and material processes - supply, production and marketing.

An important condition of this approach is the need for logistics management and maintenance, especially for the purpose of maximizing the goods.

The flow of finished materials and products, as well as the flow of Labor and information resources are considered as one of the most important parameters that ensure the adequate functioning of a single agrarian education.

Technical resources and support are defined as a unified integrated management and control system structured within a separate system and are designed to ensure more efficient use of its components, procurement systems and distribution in these functions as a whole.

The structures that fully implement all the aspects of this approach have not yet received widespread distribution in the agrarian sector, but now we can distinguish two of the most promising areas in which the evolution of the organizational mechanism for stock management in integrated agricultural facilities takes place.
The first direction is associated with further intensification of the specialization of linear-functional structures. The supporters of this direction insist on the need to create a unified material flow management system, the leader of which will be fully responsible for the movement and use of all material resources and stocks in integrated agricultural facilities from the moment of creation of material and technical support to the moment the finished products are sold to consumers. The creation of such an integrated system is aimed at overcoming the shortcomings and contradictions that arise during the formation of two different subsystems the "material management subsystem", which combines the logistics management functions at the supply stage and during production, and the "product distribution subsystem", combining the functions of flow management of finished products in the marketing process.

The second direction, which receives due attention, is the attempts to use logistic structures in the sphere of the management of material assets. The emergence and development of these organizational forms with increased dynamism are associated with the use of the basic ideas and requirements of a systematic approach to the management of the agro-industrial complex.

The most important property that determines the practicability of the use of logistic systems in the movement regulation of material and technical values is the presence of various integrating and coordinating mechanisms in them, which make it possible to intensify the work of the administrative and managerial structure not by the increase of the number of its subsystems, but solely by the increase of coordination in separate units, eliminating contradictions between subsystems, duplicating functions, increasing flexibility in interactions, etc.

\section{Conclusion}

To conclude with, we can state that at the present stage of the development of agrarian sector, there is still no universally accepted theoretical and methodological basis for the development and implementation of logistics systems for the management of material and technical support and stocks in integrated agricultural facilities of various production specializations. Agricultural enterprises are being reformed and improved on individual basis, according to the specific production and market conditions and the problems facing them. The process of the introduction of progressive organizational forms is also slowing down due to the fact that the leadership of integrated agrarian formations is afraid of unforeseen complications and interruptions in the work of the administrative apparatus, and prefers to introduce new organizational forms only when the use of old ones becomes completely impossible. 


\section{References}

1. Sh.M. Gazetdinov, M.Kh. Gazetdinov, O.S. Semicheva et al., BIO Web of Conf., 17 (2020) Retrieved from: https://doi.org/10.1051/bioconf/20201700026

2. N.F. Kashapov, M.M. Nafikov, M. Gazetdinov et al., IOP Conf. Ser. Mater. Sci. and Engineer., 412, 012038 (2018)

3. A.R. Battalova, F.N. Mukhametgaliev, F.F. Mukhametgalieva, L.F. Sitdikova, J. of Environ. Treatment Techniques, 7 (Special Issue), 930-934 (2019)
4. P.B. Akmarov, O.P. Knyazev, N.A. Suetina, Bull. of the Dagestan State Techn. Univer., 2(37), 112-118 (2015)

5. F.N. Mukhametgaliev, L.F. Sitdikova, F.F. Mukhametgalieva et al., Stud. on Russ. Econ. Development, 2(30), 162-165 (2019)

6. A.R. Valiev, F.F. Muhamadyarov, B.G. Ziganshin, Russ. Agricult. Sci., 2, 194 (2017)

7. G.P. Zakharova, Bull. of Kazan State Agrar. Univer., 4(38), 16-19 (2015)

8. L.G. Ibragimov, I.N. Safiullin, E.F. Amirova, Bull. of Kazan State Agrar. Univer., 3(50), 116-121 (2018) 